\title{
The Identification of Religious Character Values on Serenade Senja
}

\author{
Dian Tri Riska Ekawati \\ pentul.imoet2@gmail.com \\ Mutmainnah Mustofa \\ inamustofa@unisma.ac.id \\ Saiyidi Hasbullah \\ hasbullahsaiyidi@gmail.com \\ Universitas Islam Malang
}

\begin{abstract}
This study aimed at identifying the religious character values and to describe them presented by the main figures in Serenade Senja. It was conducted by qualitative research. The procedure of the research was reading the book repeatedly, focusing on religious values explained in the book, adding some references relevant to this study, and searching various sources to analyze the data. The religious values were found in three short stories namely KepunyaanMu, Kertas Kusam, and Serenade Senja. The characters of this story were described as religious characters. They did the worship diligently, remembered Allah anytime, kept promises, respected and supported others, being sincere, respectful, friendly, and grateful in their life. Those characters could be analyzed from the various part of the story. It could be concluded that literature becomes a media to convey the message which is available in the story to make the reader gaining the benefit and actualizing in real-life so that the life becomes better life in the next future.
\end{abstract}

Keywords: Religious; Character Value; Short Story

\section{INTRODUCTION}

The implementation of Indonesia's education policy to prepare the golden generation of 2045 is to equip students with 21 st century skills. These skills are integrated through character education, basic literacy, and competence in education. The main values of character education include religion, nationalism, independence, mutual cooperation, and integrity. According to Kemdikbud.go.id, basic literacy is how students apply basic daily skills consisting of language, numeracy, science, digital, financial, cultural, and civic literacy. Whereas competence is how students solve complex problems that are done with 4C namely critical thinking, creativity, communication, and collaboration. 
Lickona (1992: 12-22) mentions three main things in character education, namely knowing, desiring, and doing the good. Lickona further stated that "character education is the deliberate effort to help people understand, care about, and act upon core ethical values." Elkind (2004) states that exemplary attitudes of teachers such as teacher behavior, speech, and teacher tolerance which will ultimately shape the character of students are also character education. Character education is the thoughts and behavior of each individual as a provision for society in various environments (Suyanto, 2009). Khan argues (2010: 34) character education is a series of activities that are planned and full of awareness to improve human quality.

Considering the importance of character education for students, this character education needs to be implemented by schools consistently and can have a real impact. Fitri (2012: 156) states that learning activities can be integrated with character education in various subjects. Furthermore, she states that the internalization of character education in various learning materials needs to be developed, and linked to the context of everyday life, and provide real experiences for students. The implementation of educational character in the school can be conducted by guiding and accustoming the good deed such as honest, obey, respect each other and politeness in the school to the students moreover to the teachers.

The study of educational character can be conducted to various subject namely the process of learning a language, learning media of language, a work of literature, a work of literature of children and so on. Talking about literature it must be dealing with the personal feeling in general. Yuliani et al (2013) says literature is a personal expression of feeling, including experience, idea, motivation, and confidence in the concrete description by using language. To recognize someone's personalities it should learn literature as it is containing the hidden meaning. Talking about literature also talking about character that educational character become trending topic in the life of the society. This is the power of solving a problem.

Afiifah Al-Rosyiidah (2013) says that the good literature is a book which is for the children containing the interesting contain and clear writing. Short story is also part of literature which also has intrinsic elements they are theme, plot, setting, character and point of view. Theme describes about what the main point of the story. While the plot is the series of the story which arranged variously by actuating the way of the story from the first, middle, then to the climax and the final of the story. Setting is the description of place, situation that occurred of the event. Character is the inner nature that affects all minds and behaviors.

The writer consider this is a great writing to propose the reader about some characters that can be taken the benefit. The aim of this study is to identify the religious character values and to describe them presented by the main figures in 
Serenade Senja. It is a short story compilation consisting of three appealing stories, KepunyaanMu, Kertas Kusam, and Serenade Senja.

\section{LITERATURE REVIEW}

\section{Previous Related Study}

A number of studies discussing about the character education have been presented by some findings. Rr. Astri Indriana Octavita and Ria Saraswati (2017) this study is to integrated between character education and teaching of English Language for kindergarten In LPI Nur Hikmah Kampung sawah. The output of this result is the ability of teachers to implement character education in learning English then the values of the character education of this study are friendly, caring, social, curiosity, democratic, independent hard work, discipline, and love to read.

Swastini et al (2017) this study is to identify the character values to the main character of Zootopia. The procedure of this study is streaming to collect the data from the plot, story and film setting. There are 17 values education character found in this study they are: work hard, discipline, responsible, creative, respect the achievement, stand alone, and love peace. Some characters found from the above explanation is to encourage to be better life in the next future.

Mutmainnah Mustofa et al (2020) also discuss about a character which is part of literature the tittle is Iskamic Character education in E-learning model: How should be implemented? This research is focused on teachers' and students' perception, curriculum and material developments. In this research is using participatory Action Research (PAR) this research says that if the proposal implemented by teachers will give the great contribution which finally will have much more benefit.

\section{Character Values}

Being discussed about character values it must be a definition of it. And the writer will elaborate the definition one by one. Character is attribute or feature that makes up and distinguishing the individual; the complex of mental and ethical traits making person, group or nation while the value is hold in high esteem; regards highly (Linda, 1997).

Further, Kemdikbud (2017) explains that the Indonesian government has proposed the primary program purposed to build the character namely Penguatan Pendidikan Karakter (PPK). The five major character values in PPK as follows religion, nationalism, integrity, independence, and mutual cooperation. The source of them is Pancasila. Those character values interact with each other and develop dynamically. 


\section{Religious Character}

This occasion also need to elaborate what the religious character is. The value of religious character according to the Ministry of Education and Culture must show religious behavior towards God Almighty such as always worshiping, being tolerant, and creating harmony with others. The implementation of these actions is like always being confident, having a firm stand, sincere in applying an action, caring for and loving the environment, and never imposing a will on adherents of other religions.

Ahmad Nadhif (2012) stated that religion is one of the main references of moral values, especially in pre-secularism era. As the religious character is crucial in the life of social interaction the example of religious characters is patient, generous, and also good manner such as polite. In this analysis the writer will discuss about the religious character dealing with patient by always gratitude on to Allah the almighty in every situation.

The writer can infer that character and values are the terms that cannot be separated which describe the individual traits the people can be identified by their characters whether they have good or bad character. For example in this article the writer analyzed the character of Serenade Senja that the actor or actress has a character value namely religious character which will discuss below.

\section{Short Story}

According to Wikipedia, the oldest type of literature is a short story. It means fiction that can evoke the readers' mood. The reader spends around 20 minutes to an hour reading one short story. Furthermore, a short story contains 1.000 to 7.500 words.

Blurb (2019) added that at first, a short story has been performed in written. The old kinds of short stories are fable, fairy tales, anecdotes, folk stories, and legends. They could be found in a whole world. The latest short stories are arising in 19 th century. Some authors are considered the founder of them. They are Edgar Allen Poe and Anton Chekov. Those stories come in various kinds of categories namely horror, fantasy, action, adventure, comedy, crime, politics, romance, mystery, science, and even biography.

A short story has a simple setting. It contains one time, place, and one or two main characters. Those characters have never been accompanied by full backstories. A short story displays the content using a single plot. It distinguishes it from a novel that has multiple plots. Some common stories use narrative generic structure namely orientation (at the beginning), conflict, climax (peak moment), and resulted in resolution and usually, there is a moral message conveyed by the author implicitly. 


\section{METHOD}

\section{Design and Sample}

The study is conducted by qualitative research. Cresswell, J (1998: 24) states that qualitative research is research designs using data in form of descriptive and resulted in both written and digital records. This source of study is Serenade Senja book. The book is a compilation of short stories. They are KepunyaanMu, Kertas Kusam, and Serenade Senja. The study offers on describing the values of character education on the main discussion is religious values. Non-instrument test is used in gathering the data.

\section{Procedure and Instruments}

Referring to the previous statement, qualitative research involves non-numerical data such as video, audio, and text to collect and analyze to understand the concepts, opinions, and experiences. This method is used commonly in various fields of study as follows anthropology, sociology, education, history, and health sciences. Suwastini, Swandana, and Payani (2017) did qualitative research to analyze the values of characters' education on the main character of the film, Zootopia. The study used close reading in collecting the data from the plot, story, and setting of the film. Furthermore, Yuliani, Markus, and Abdul Waris (2003) in her study used qualitative research focused on analyzing literary particularly on the main characters and the plot in Habibie \& Ainun's novel. This study also works in analyzing literature. This source of study is Serenade Senja book. The book is a compilation of short stories. They are KepunyaanMu, Kertas Kusam, and Serenade Senja. The study offers on describing the values of character education on the main discussion is religious values. Non-instrument test is used in gathering the data.

\section{Data Analysis}

In analyzing data, the writer conducted several steps. First, the writer read the book "Serenade Senja" repeatedly. Then, the writer focused on religious values explained in the book. Next, some references which are relevant to this study were added. The last, the writer searched various sources from the internet to support in analyzing the data.

\section{RESULT AND DISCUSSION}

\section{KEPUNYAANMU}

KepunyaanMu is written by Hamano. It was told about a young girl who had ear defects since birth. One day she got an accident lost her handphone when she went home. There is a sense of blaming God for what happened. Since she did all the good deeds during her life, but misfortune still befell her. Moreover, she had 
to give up his savings for ear surgery to replace her lost handphone. Eventually, she realized her mistake. Religious values are found throughout the story. They are as follows:

\section{Doing the worship}

The main character always did the worship diligently. It is shown in some sentences. It is stated clearly by the sentence, "Selepas sholat ashar, kusentuh mushaf di sampingku. Aku lantunkan ayat-ayat suci firman-Nya yang begitu indah." The word "Aku lantunkan ayat-ayat suci firman-Nya yang begitu indah", it means that she does kindness that is read Holy Al Qur'an. It belongs to religious values as it is one of obligation as a Muslim. Reading Holy Al Qur'an will help us to make our hearts is calm.

The character not only did the fardhu but also sunnah is performed. "Membaca buku, tilawah, puasa ramadhan, sholat dhuha, sholat tarawih, zikir pagi dan petang, membantu orang tua, sedekah, semua sudah dilakukan." Based on the explanation, it can be analyzed that the main character in the story "KepunyaanMu" want to obey Allah. She did Ramadhan fasting. As a moslem we must do it because it is one of the Islamic foundation. Furthermore, by doing Ramadhan fasting can make us healthier.

\section{Remembering Allah}

As Wikipedia stated "Dhikr literally means remembrance, reminder Allah", the character in short story "KepunyaanMu" proved it. It is shown at the beginning of the story, the character recited dhikr,

“Astaghfirullahal'adziim... Astaghfirullahal'adziim... Astaghfirullahal'adziim. Tak henti-hentinya lantunan zikir membasahi bibirku."

The word "Astaghfirullahal'adziim" shows that she was being regretful and apologize to Allah because of her sin.

“Allahu Akbar!, spontan langsung aku menge-gas motor mencari handphone-ku yang sepertinya terjatuh di sepanjang jalan perjalanan pulang."

The word "Allahu Akbar" proves that she always remembered Allah anytime. That time, she realized that her handphone was lost when she went home.

\section{Being friendly}

"Air mata tiba-tiba jatuh begitu saja, padahal aku sedang tersenyum berusaha menutupi keganjilanku. Temanku yang menyaksikan langsung merangkulku penuh iba. Tangisanku pecah tiba-tiba. Udah, Rif. Mungkin itu belum rejekimu. Ujian Ramadhanmu udah datang. Yang sabar, kamu harus kuat. 
Ambil air wudhu terus sholat dzuhur biar tenang. Ujar Euis, salah satu sahabat merangkulku."

The previous sentence is emphasized that sub values of religious namely friendly is shown by the writer. Another prove is

"Namun, dengan desakan dan nasehat teman-temanku, ku beranikan diri melapor kepada kedua orang tuaku."

\section{Being sincere}

Being sincere is explained in this story. The character eventually used her saving to buy a new handphone. Even though, that saving would be used to operate her ear.

"Kini, uang yang kukumpulkan dari hasil menyisihkan uang jatah bulanan harus kuikhlaskan untuk keperluan yang lebih mendesak. Tak apalah, uang yang terkumpul juga baru tujuh ratus ribuan yang cukup untuk membeli handphone. Soal lain dapat dipikirkan kemudian. Toh, aku punya Allah yang Maha Mampu. Segalanya mungkin lewat kehendak-Nya."

The moral value can be learned from this story is we should always have a positive thinking and do not blame Allah of whatever happens in our life. Ensure that Allah give us the best all time. It is concluded by the sentence

"Barangkali kita sering mendengar teman kita yang kehilangan sesuatu yang kita cintai dan menyalahkan Allah. Adapula yang berprasangka bahwa amalannya sia-sia karena terus menerus ketiban sial. Perlu adanya pelurusan bahwa anggapan-anggapan itu hanya akan memunculkan sikap tidak ikhlas dalam beramal. Padahal, banyak kemungkinan alasan mengapa Allah memberikan ujian kepada kita. Itulah tugas kita untuk menguak keindahan hikmah di baliknya."

\section{KERTAS KUSAM}

The second story, Kertas Kusam, was told by Azka Hariz. It can be summarized that the boy named Bujang wants to achieve his goals in the midst of the limitations of his family life. He passed the entrance test in one of favorite campus in Yogyakarta. When he told it to his parents, his father did not express his happiness because of a lack of funds. Bujang could not accept it. Because of his anger, he decided to leave his home and his parents. His father only gave him a Holy Qur'an, yet he refused it. Several years later when Bujang has become a successful entrepreneur, he remembered his parents. Arriving at his home, he found that the Holy Qur'an still laid on the table just as he left. When he opened that Qur'an, he saw a paper that showed that his parents had paid all his school fees. His regret would change nothing as his parents had died away. The writer wrote some religious values in this story namely: 


\section{Being respectful to parents}

Bujang is the child who obey their parents. It can be shown by the sentence.

"Mandi dulu sana, setelah itu bergegas pergi ke mushola." Pesan ibu kepadaku. "Siap laksanakan! Jawabku dengan semangat sembari bergegas lari ke kamar mandi." Without delaying, Bujang did her mother command. "Bapak, ibu, aku berangkat dulu. Setelah berpamitan, aku melesat keluar rumah pergi ke musholla yang letaknya empat rumah dari rumahku."

The presented sentence can be analyzed that Bujang is a polite boy. Wherever he went, he always asked permition from his parents. Religious values can be seen from being respectful to the parents as it is one of religious orders that we must carry out.

\section{Doing the worship}

"Aku merupakan anak yang rajin. Sholat tepat waktu, mengaji setiap malamnya, belajar dengan giat, dan tak pernah lepas dari yang namanya juara kelas."

The word "sholat tepat waktu and mengaji setiap malamnya" proves the religious values, did the worship diligently. From this sentence, the writer wants to show to the reader that Bujang always did the prayer on time and read the Holy Qur'an. It can be a good example for us.

\section{Having strong determination}

Bujang is described as character who has strong determination in achieving his dream.

"Sebenarnya tak tega hati ini melihat ibu mulai meneteskan air matanya. Tapi ketetapan hatiku sudah bulat, aku harus merantau pergi sekarang. Apa pun yang akan terjadi, aku akan membuktikan kesuksesanku di luar sana."

It can be concluded that Bujang insisted to go. He wanted to prove to anyone that he could gain his dream whatever will be. The strong determination is one of religious value. It can be a good motivation for us to do our will.

\section{Keeping promises}

Another religious value from this story is keeping promises.

"Ayo nak, besok liburan kita kesana ya. Okee yah. Janji lho ya. Alya pengen banget ketemu sama kakek Alya." "Perjalanan panjang kutempuh untuk kembali 
ke rumah bersama istri dan Alya. Tidak ada percakapan. Hingga sampailah kami di rumah kedua orangtuaku."

As a father, Bujang kept his promise to Alya, her daughter, accompanied her to meet her grandparents even though Bujang did not see his parents for several years. Keeping promises is a religious obligation. Moreover, it creates a connection between God and the individual. We should never break promises as it is not allowed in Islam. It can lead to breaking the trust of others. Islam always teaches us to help and fulfill others' needs.

"Malang bukan kepalang. Kenyataan tak dapat ditolak. Kedua orang tuaku sudah tiada. Mereka pulang saat aku tak ada di sampingnya. Hancur hati ini mengetahui dua buah batu nisan terpahat nama mereka tepat berada di depanku. Hujan seakan-akan ikut menemani tangisanku. Andaikan disaat terakhir percakapan dengan mereka dalam keadaan baik. Andaikan aku mengikuti apa kata ibu. Andaikan aku tidak membentak Bapak malam itu. Andaikan aku tidak pergi dari rumah. Apakah aku harus menyusul ke surga untuk meminta maaf? Kurasa itu saja tak cukup. Diriku sudah tak layak menginjakkan kaki di tanah surga."

It can be inferred from the last part of the story that Bujang fell so guilty for leaving his home and hurting his parents' heart. He could not ask forgiveness as his parents had died away. The valuable lesson can be learnt is we must respect our parents even though we often have different opinions with them. We should never hurt our parents so that we don't regret it.

\section{SERENADE SENJA}

It was talking about a family that has religious life style. Suryaning Mentari is the name of the girl whose brother is very calm and patient, his name is Ilham. Her father is a fisherman and her mother is a house wife. She lived near the beach that's why she helped her father to gain money by renting a mat to the tourism on the beach. Her daily life was spent with her friend playing on the beach while attempting to gain money by renting the mat. Some religious values can be found in this story written by Anisah Idzihar.

\section{Remembering Allah}

"Masih teringat jelas dalam bayanganku ketika Mas Ilham menghadapi detik" terakhirnya. Tangannya amat dingin. Kata Mamak, wajahnya yang tampan itu nampak pucat sekali. Meski begitu, ia tak pernah merintih kesakitan, apalagi menangis. Hanya lantunan tasbih dan nama-Nya yang samar terdengar sebelum malaikat Izrail menghampirinya. Memoriku berhenti sampai disitu, lalu mengembalikan kesadaranku ketika akan memasuki ruang operasi. Aku hanya bisa pasrah dan menyerahkan semua kepada-Nya. Samar" 
The above part of story told everyone whatever it takes must be in remembering Allah the almighty. Reciting tasbih is proof that the character of her brother is really religious although he was sick still performing a dzikr. This also teach Aning to always make Allah become number one in every situation. That's why Aning was surprised and proud of her brother.

\section{Supporting and respecting each other's}

Her family attempted to support each other when her family had a problem

“Aning nggak pernah membangkang Mamak dan Bapak. Aning nggak pernah absen mengaji pada Kyai Harris di langgar. Aning nggak pernah curang dan merebut lahan orang ketika menyewakan tikar. Kenapa Allah menghukum Aning demikian, Bang? Apa Allah nggak sayang lagi.., " ujarku yang dipotong Mas Ilham segera. "Ini takdir dari Allah, Ning. Kamu harus menerimanya dengan lapang dada. Ujian itu diberikan tak lebih berat dari pundak yang menanggungnya. Allah memberi ujian kepada kamu, karena Allah sangat menyayangimu. Inget kata Kyai 'Apakah kamu mengira bahwa mereka dibiarkan saja mengatakan : Kami telah beriman, sedang mereka tidak diuji lagi?'. Hadapi semua dengan sabar dan ikhlas, Ning," jelas Mas Ilham mencoba menenangkan pikiranku. Namun aku masih khawatir akan nasibku, masa depanku, dan apa yang akan kulakukan setelah ini.

The above sentence shows us that whatever occurs to our life in this universe we must be back to the almighty God Allah by being gratitude and always encourage the one who has calamity by remembering Allah the almighty. Strengthening by taking and giving is an effective way to respect others with a motivation such as "Sssstt. Tidak ada manusia yang tidak berguna selama masih ada Iman, Islam dan Ihsan di dalamnya, Ning. This value describe that the people should remind each other to make them strong and always give thanks to Allah that has known the best for His creature.

\section{Gratitude to Allah}

"Perlahan aku mulai rela dan ikhlas menerima apa yang terjadi padaku. Allah hanya mengambil satu dari empat indera yang dianugerahkan kepadaku. Lantas alasan apa yang menjadikanku tidak bisa bersyukur?"

This statement also shows that Aning lived in the environment of religiousness so that easily aware that everything occurred in this universe must be a benefit that should gratitude to Allah. As presented in holy Qur'an whoever gratitude to Allah, He will give more.

\footnotetext{
"Aku duduk di tangga depan, memandang lurus ke arah laut seperti yang sering dilakukan Mas Ilham dulu. Bersyukur bahwa masih diberi kesempatan untuk melihat lagi, meski dengan mata maniknya."
} 
This statement shows that Aning also good person. She always gratitude to Allah as she got a chance being able to see once more. Gratitude to Allah is also the value showing the religiousness as this is also recommendation from Allah the almighty.

The moral value that can be learned from this story is to always gratitude in every situation we meet whatever occurs in the life whether it is good or bad according to us the crucial is to gratitude to Allah that Allah will give more

"Hidup itu bukan sekedar menerima, tapi juga tentang bersyukur pada-Nya. karena syukur membuat hati kita lapang. Kelapangan hati membuat mata yang sempit terbuka lebar. Bahwa sakit dan susah ini mungkin tak seberapa jika dibanding lainnnya," Mungkin setelah ini aku akan lebih memaknai senja, yang serenadenya berisi petuah-petuah lelaki itu. Lalu mengucap syukur di setiapnya. Sebab Allah pernah menghadirkannya dalam keluargaku. Lelaki yang mencintaiNya sebelum mencintai kami.

\section{CONCLUSION}

The religious values were found in three short stories namely KepunyaanMu, Kertas Kusam, and Serenade Senja. The characters of this story were described as religious characters. They did the worship diligently, remembered Allah anytime, kept promises, respected and supported others, being sincere, respectful, friendly, and grateful in their life. It could be concluded that literature becomes a media to convey the message which is available in the story to make the reader gaining the benefit and actualizing in real-life so that the life becomes better life in the next future.

\section{REFFERENCES}

Affiifah, A. (2013). Character education in classic fairy tales. Jurnal Pendidikan Karakter, 3(3), 250-263, doi:10.21831/jpk.v0i3.2748

Ahmad, N. (2012). Religious character values in indonesia's character education. Jurnal Pendidikan Islam, 27(1), 128-141, doi: https://doi.org/10.15575/jpi.v27i1.500

Aminuddin. (2002). Pengantar apresiasi karya sastra. Bandung: Sinar Baru Algesindo.

Akhmad R.T. (2020). Pudarnya kuasa negara: Analisis cerpen-cerpen seno gumira ajidarma dalam perspektif foucault. Mimesis Journal, 1(1), 33-39, doi: $\underline{10.12928 / \mathrm{mms} . v 1 \mathrm{i} 1.1535}$ 
Cresswell, J. (1998). Research design: qualitative \& quantitative approaches. Thousand Oaks California: Sage Publications.

Dhikr. (2021, April 17). Retrieved April 26, 2021, from https://en.wikipedia.org/wiki/Dhikr

Elkind. (2004). How to do character education. Retrieved April 27, 2021, from https://www.googcharacter.com/Article_4.html

Fitri, A.Z. (2012). Pendidikan karakter berbasis nilai dan etika di sekolah. Yogyakarta: Ar-Ruzz Media.

Hamano, Azka Haris, \& Anisah Izdihar. (2016). Kumpulan cerpen serenade senja. Retrieved from: https://www.coursehero.com/file/40675907/Cerpen$\underline{\text { Serenade-Senjapdf/ }}$

Jaenudin, Nanang K, \& Raden M.I. (2018). Analisis penggunaan gaya bahasa dalam antologi cerpen mawar hitam karya candra malik. Jurnal Pendidikan Bahasa dan Sastra Indonesia, 1(3), 405-416, doi: $\underline{10.22460 / \text { p.v } 1 \mathrm{i} 3 \mathrm{p} \% 25 \mathrm{p} .763}$

Khan, Yahya. (2010). Pendidikan karakter berbasis potensi diri. Yogyakarta: Pelangi Publishing.

Lickona, Thomas. (1992). Educating for character: how our school can teach respect and responsibility. New York: Bantam Books.

Mustofa, M. (2018). Character building through poem. Surabaya: Pondok Pesantren Jagad 'Alimussiry.

Mutmainnah Mustofa, Rulam Ahmadi, \& Imam Wahyudi Karimullah. (2020). Islamic character education in e-learning model: how should it be implemented?. Jurnal Sains Sosio Humaniora, 4(1), 89-93, doi: $\underline{10.22437 / j s s h . v 4 i 1.9771}$

Pengelola Web Kemdikbud. (2017, July 17). Penguatan pendidikan karakter jadi pintu masuk pembenahan pendidikan nasional. Retrieved from https://www.kemdikbud.go.id/main/blog/2017/07/penguatan-pendidikankarakter-jadi-pintu-masuk-pembenahan-pendidikan-nasional

Ratih S, Imas M, Pipin P, \& Dida F. (2018). Analisis struktural dan nilai moral dalam cerpen "kembang gunung kapur" karya hasta indriyana. Jurnal Pendidikan Bahasa dan Sastra Indonesia, 1(2), 101-114, doi: $\underline{10.22460 / p . v 1 i 2 p 101-114.79}$ 
Rr. Astri Indriana Octavita, \& Ria Saraswati. (2017). The integration of character education in teaching english. Jurnal Terapan Abdimas, 2, 33-40, doi: $\underline{10.25273 / \text { jta.v2i0.974 }}$

Rudi E. (2020). Analisis cerpen robohnya surau kami karya a.a. navis dalam perspektif posmodernisme linda Hutcheon. Gadjah Mada Journal of Humanities, 4(1), 34-45, doi: 10.22146/sasdayajournal.54566

Scerenko, L. (1997, August). Values and character education implementation guide. $\quad$ Retrieved from http://www.edpsycinteractive.org/topics/affect/valuesga.html

Short_story. (2021, April 5). Retrieved April 30, 2021, from https://en.wikipedia.org/wiki/Short_story

Susana F.L, Zaki A.F, \& Yuliani R. (2016). Analisis struktur dan nilai-nilai moral yang terkandung dalam cerpen ten made tokode karya yoshida genjiro. Jurnal Japanese Literature, 2(2), 1-10. Retrieved from https://ejournal3.undip.ac.id/index.php/japliterature/article/view/12451

Suwastini, N.K.A., Swandana, I.W., \& Payani, N.L.P.D. (2017). The identification of character education values on the main character of zootopia. Jurnal Pendidikan Bahasa Inggris Undiksha, 2(5), doi: 10.23887/jpbi.v5i2.14955

Suyanto. (2009). Urgensi pendidikan karakter. Retrieved from http://konselingindonesia.com/index.php?option=com_content\&task=view $\underline{\text { \&id }=307 \& \text { Itemid }=102}$

Yasnur, A. (2011). Analisis sosiologis cerpen si padang karya harris effendi thahar. Humaniora Journal, 23(3), 245-255, doi: $\underline{10.22146 / \mathrm{jh} .1026}$

Yuliani, Markus K Salombe, \& Abdul Waris. (2013). An analysis the main characters and the plot in the novel of Bacharuddin Jusuf Habibie's. $e$ Journal of English Language Teaching Society (ELTS), 1(1), 1-14. Retrieved from: http://jurnal.untad.ac.id/jurnal/index.php/ELTS/article/view/1684 